\title{
Public Interest Litigants in the Court of Session
}

When Lords Hope and Reed reformed the law of standing in AXA General Insurance v Lord Advocate $^{1}$ they grounded that change firmly in constitutional principle. To restrict standing to those for whom a private right or interest is at stake was, in Lord Reed's view, "incompatible with the courts" function of preserving the rule of law," precisely because "[a] public authority can violate the rule of law without infringing the rights of any individual."2 Thus, their Lordships agreed that (in public law judicial review cases at least) the time had come to consign the title and interest test to the dustbin. For Lord Reed, drawing a direct parallel with the approach taken in England and Wales, the correct terminology must now be standing, based on sufficient interest. ${ }^{3}$ For Lord Hope, the words "directly affected", construed broadly to include those acting with genuine concern for the public interest even in the absence of any private right or interest of their own, was appropriate. ${ }^{4}$ A difference of terminology aside, it is clear that in terms of the substantive effect of this change the Scottish justices were as one: judicial review in Scotland would no longer be about private rights and individual grievances but (to borrow from Sedley J) about public wrongs and the maintenance of the rule of law. ${ }^{5}$ It would seem, however, that the Court of Session has so far pushed back against the public interest justification for judicial review that underpins this shift, restricting opportunities for public interest litigants to appear either as petitioners or as public-spirited interveners. This article seeks to explain that claim.

\section{A. STANDING}

The lines of resistance were first drawn by the Court of Session in Walton $v$ Scottish Ministers, ${ }^{6}$ a statutory appeal ${ }^{7}$ in which Mr Walton sought to challenge the validity of certain

\footnotetext{
${ }^{1}$ [2011] UKSC 46; 2012 SC (UKSC) 122 at paras 53-56 per Lord Hope; at paras 155-175 per Lord Reed.

${ }^{2} A X A$ at para 169.

${ }^{3}$ Para 171.

${ }^{4}$ Para 63.

${ }^{5} R v$ Somerset County Council ex p Dickson [1998] Env LR 111 at 7 per Sedley J.

${ }^{6}$ [2012] CSIH 19.

${ }^{7}$ Roads (Scotland) Act 1984, Sch 2 para 2.
} 
orders and schemes made by the Scottish Ministers relating to the construction of a new road network on the periphery of Aberdeen. In determining whether he was (in the language of the relevant statute) a "person aggrieved" and therefore entitled to raise proceedings, the Inner House held that Mr Walton had failed to demonstrate that the construction of the road had any substantial impact upon his interests, or would negatively affect his property. Moreover, the opinion went on to add that, had this been an exercise of the supervisory jurisdiction and not a statutory appeal, the court would have been minded to hold that Mr Walton lacked "sufficient interest" at common law, not least because of the considerable geographical distance between his property and the new route. If the narrow interpretation of Mr Walton's interests here looked like a subtle attempt to reintroduce the restrictions of the title and interest test under the guise of sufficient interest (the emphasis being placed on his rights, his interests), it was an attempt to which the Supreme Court, on appeal, gave short shrift. ${ }^{8}$ Despite the fact that Mr Walton's entitlement to bring proceedings had not been contested by the Scottish Ministers, Lord Reed took the opportunity to reinforce the spirit and the implications of $A X A$. In pointed disagreement with the Inner House, his Lordship concluded that Mr Walton - who had demonstrated a genuine concern about the proposal, and who had been an active member in organisations concerned with the environment generally and with opposition to new route specifically - ought to have had standing as a party with a sufficient interest, though those proceedings would likely have failed on their merits. The court's constitutional function of maintaining the rule of law, he said, could no longer be ignored in favour of "an approach which presupposed that the court's supervisory jurisdiction was to redress individual grievances." 9

That a proper interpretation of $A X A$ and Walton required the Court of Session to take a qualitatively different approach to standing can be seen in the contrasting treatment given to that issue by the Outer and Inner Houses in McGinty $v$ Scottish Ministers. ${ }^{10}$ Marco McGinty, a keen birdwatcher and member of the Royal Society for the Protection of Birds ("RSPB"), sought to challenge the designation of a new power station and transhipment hub at Hunterston as a "national development", thereby giving it priority in any subsequent application for development consent, on the basis that statutory requirements for public consultation prior to designation were not complied with. In the Outer House, Lord Brailsford

\footnotetext{
${ }^{8}$ Walton v Scottish Ministers [2012] UKSC 44; 2013 SC (UKSC) 67 (henceforth "Walton (SC)").

${ }^{9}$ Walton (SC) at para 90.

${ }^{10}$ See respectively McGinty v Scottish Ministers ("McGinty (OH)") [2011] CSOH 163 and McGinty v Scottish Ministers ("McGinty (IH)") [2013] CSIH 78.
} 
declined to delay his opinion until the Supreme Court's judgment in $A X A$ had been handed down, and - applying the test of title and interest - dismissed the petition. Whilst the Lord Ordinary took the view that Mr McGinty might have had title to sue in order to "prevent a breach by a public body of a duty owed to the public by that body", ${ }^{11}$ as an individual who resided some five miles from the land in question, and whose only connection to that land was to use it infrequently for recreational purposes, his Lordship concluded that Mr McGinty could not be said to have had a "real and legitimate" or "real and practical" interest in the matter, capable of enforcement by the court. ${ }^{12}$ Following the Supreme Court's decisions in $A X A$ and in Walton, however, when the petition was reclaimed to the Inner House that court felt bound to adopt a different approach. Agreeing with Lord Reed that the rule of law would not be maintained if, because everyone was equally affected by an unlawful act, no-one was able to challenge it, ${ }^{13}$ Lord Brodie held that, (although ultimately unsuccessful on the merits) "applying the approach now desiderated by the Supreme Court" it was no longer permissible to dismiss Mr McGinty as a mere busybody. ${ }^{14}$ His Lordship considered as relevant the petitioner's concern for the environment and for the activity of birdwatching; his knowledge of both; and his willingness to make representations during any consultation process that preceded the decision. ${ }^{15}$

We should not, however, rush to the conclusion that McGinty marks the last word on the question of standing or the final acceptance (or, acceptance finally) by the Court of Session of the liberal approach envisaged in AXA and in Walton. Whereas in England and Wales it is extremely rare for applicants to fail to clear the hurdle of sufficient interest, in Scotland the question of standing remains a substantial (if reduced) obstacle. So, in Christian Institute v Lord Advocate ${ }^{16}$ Lord Pentland appeared to construe narrowly the "directly affected" test when he refused standing to four of seven petitioners, holding that a failure by the Christian Institute, the Family Education Trust and the Young ME Sufferers Trust to engage in the consultation exercise which preceded the Children and Young People (Scotland) Act 2014, and the general and insubstantial response to that consultation made by CARE, betrayed a lack of genuine concern for the legislation and its effects. ${ }^{17}$ Additionally,

\footnotetext{
${ }^{11} \mathrm{Mc}$ Ginty $(\mathrm{OH})$ at para 25 per Lord Braislford.

12 Para 26.

${ }^{13}$ McGinty (IH) at para 46.

${ }^{14}$ Para 48.

${ }^{15}$ Para 48.

16 [2015] CSOH 7.

${ }^{17}$ Para 93.
} 
the Lord Ordinary took the view that none of these organisations possessed sufficient expertise to be deemed properly representative of the public or a section thereof who might be said to be directly affected by the scheme, adding that the rule of law would not be compromised in this case as the competence of the legislation would be tested by three more petitioners, whose children it would impact directly. ${ }^{18}$ In both McGinty and Christian Institute we see $A X A$ and Walton applied in ways which lower the threshold of standing but which, by requiring public interest litigants to be fully engaged in prior political processes and to be possessed of expertise in lieu of enforceable legal rights, nevertheless impose a more substantial barrier to litigation than might be placed before their counterparts in England and Wales. It is an approach which still focuses too heavily on the characteristics of the petitioner rather than the public interest in hearing the petition.

\section{B. THIRD PARTY INTERVENTIONS}

The Court of Session has taken a similarly resistant approach to the question of third party interventions brought in the public interest. In England and Wales, and in the Supreme Court, such interventions occur frequently and have been praised (though, it must be said, not universally so ${ }^{19}$ ) by academics, ${ }^{20}$ practitioners, ${ }^{21}$ interveners themselves ${ }^{22}$ and, crucially, by judges $^{23}$ for the value that they add to proceedings. As Lord Hoffmann put it in $E$ (A Child) $v$ Chief Constable of the Royal Ulster Constabulary, ${ }^{24}$ so long as they avoid the mere repetition of arguments made already by the parties, ${ }^{25}$ permission is granted to interveners "in the expectation that their fund of knowledge or particular point of view will enable them to

\footnotetext{
${ }^{18}$ Para 95.

${ }^{19}$ C Harlow and R Rawlings, Pressure Through Law (1992).

${ }^{20}$ S Shah, T Poole and M Blackwell, "Rights, interveners and the Law Lords" (2014) 34

OJLS 295; L Neudorf, "Intervention at the UK Supreme Court" (2013) 2 Cambridge Journal of International and Comparative Law 16.

${ }^{21}$ M Fordham QC, "Public interest interventions in the Supreme Court" (2010) 15 Judicial Review 18.

${ }^{22}$ JUSTICE, To Assist the Court: Third Party Interventions in the UK (2009), available at http://justice.org.uk/assist-court/.

${ }^{23}$ Baroness Hale, "Who guards the guardians?" (2014) 19 Judicial Review 1.

${ }^{24}$ [2008] UKHL 66.

${ }^{25}$ Para 2.
} 
provide the [court] with a more rounded picture [of law, policy, fact or context] than it would otherwise obtain." 26

In Scotland, however, public interest interventions are viewed with some scepticism. The procedure for public interest interventions appears in rule 58.8A of the Rules of Court. Since its introduction in 2000, there is only one reported instance of this procedure being used successfully. In Scotch Whisky Association, Petitioner ${ }^{27}$ Lord Hodge allowed a charity, Alcohol Focus Scotland ("AFS"), to intervene in a challenge to the validity of the Alcohol (Minimum Unit Pricing) (Scotland) Act 2012, recognising that the challenge raised a matter of public interest (alcohol abuse and associated harm); that the intervention would neither unduly delay the hearing nor increase the costs thereof; that the analysis put by AFS in support of the contested policy was distinct from that being made by the Scottish Ministers; and that the intervention would therefore be of benefit to the court.

Subsequently, however, the record has been much bleaker. AFS themselves were refused permission to intervene by way of a 5000 word written submission when the petition was reclaimed to the Inner House. ${ }^{28}$ There, in a short (and rather blunt) opinion, Lord Eassie took the view that the point of European law upon which AFS sought to intervene had been heard but even had this not been so, the intervention would add nothing of substance to the arguments put by the parties. This seems questionable, however, not only in light of the preliminary reference made by the Inner House, which would allow two further opportunities to make substantive arguments (in Luxemburg, and again in Scotland applying the reference) but also in light of the minute of intervention, which introduced an argument about subsidiarity, and which sought to develop an argument about the role of the precautionary principle in the proportionality analysis, neither of which were dealt with in the Lord Ordinary's first instance decision. ${ }^{29}$ Furthermore, Lord Eassie took the view that AFS had sought to intervene primarily in the erroneous belief that they would (or could) by virtue of that intervention be granted the status of a "party" to the proceedings, thus enabling the applicants to secure locus standi to make written and oral arguments on the issue before the Court of Justice of the EU (“CJEU”). ${ }^{30}$ Contrast this approach, however, with that taken in the High Court in $R$ (on the application of Philip Moris Brands Sarl) $v$ Secretary of State for

\footnotetext{
${ }^{26}$ Para 1.

27 [2012] CSOH 156.

${ }^{28}$ Alcohol Focus Scotland, Applicants [2014] CSIH 64 (henceforth “AFS (IH)").

${ }^{29}$ On file with author, use permitted by AFS.

${ }^{30}$ AFS (IH) at paras 3-5.
} 
Health. ${ }^{31}$ There Turner $\mathrm{J}$ held that, although not automatically a party to proceedings as a result of having been granted permission to intervene, the expertise and perspectives offered by a number of interveners was sufficient to persuade the court to amend a preliminary reference to include those organisations to be listed as parties, thereby granting to them an opportunity to make submissions to the CJEU. ${ }^{32}$

Perhaps more surprising still, in Sustainable Shetland $v$ Scottish Ministers ${ }^{33}$ the court needed just a single paragraph to hold that the RSPB was not entitled to intervene in a reclaiming motion to the Inner House against a decision by the Scottish Ministers to grant consent for a wind farm in Shetland, with (the petitioner claimed) harmful effects on a rare bird species. ${ }^{34}$ In the Lord Justice Clerk's view, the RSPB's interest in the dispute had been recognised at the earliest stages when that body was consulted by the Scottish Ministers and made its objections to the development known. Had the RSPB wished subsequently to challenge the decision to grant consent, his Lordship continued, it had ample opportunity to do so either as a petitioner raising an action for judicial review in its own name, or by intervening in the Outer House. Thus, the court concluded that it would be "[in]appropriate to allow them to enter the process at the appellate stage under the guise of a public interest intervention." ${ }^{\prime 35}$ Given, however, that the Court of Session has no mechanism to flag up cases that might be of interest to interveners (compare the Court of Session's website with the Supreme Court's much more informative and transparent one); given the costs and the risks which attach to intervention at an early stage, and the extent to which arguments might (and oftentimes do) evolve (to the greater or lesser interest of the potential intervener) as a case progresses to the appellate stage; given finally that interveners depend to a large extent on the goodwill of the parties disclosing case documents in order to self-assess the value of their mooted contribution (goodwill that is not always forthcoming), this seems an unnecessarily restrictive approach to take to a body with undoubted expertise whose aim it was to assist the court by way of a relatively modest written intervention. In adopting so restrictive an

\footnotetext{
31 [2014] EWHC 3669 (Admin).

32 Paras 25-29.

33 [2013] CSIH 116.

${ }^{34}$ The Supreme Court dismissed Sustainable Shetland's appeal in February this year, see [2015] UKSC 4.

${ }^{35}$ Sustainable Shetland (n 33) at para 22.
} 
approach, the Court of Session is out of kilter with senior courts both within and outwith the $\mathrm{UK} .^{36}$

\section{CONCLUSION}

The Court of Session is frequently in public law cases a final court and, in devolved areas, possesses some of the characteristics of a constitutional court. Seen in this context, the judgments by the Supreme Court in $A X A$ and in Walton ought rightly to be praised for shifting the underlying justification for judicial review in Scotland away from the redress of individual grievances towards the public interest in maintaining the rule of law. For would be public interest litigants, however, the reluctance with which the Court of Session has followed that pivot presents barriers (whether structural, procedural, principled or something less tangible still) that remain to be confronted and overcome in processes of dialogue between the Court of Session and counsel on the one hand and the Supreme Court on the other.

Christopher McCorkindale University of Strathclyde

${ }^{36}$ See Neudorf (n 20); R Chateris, "Intervention - in the public interest?" 2000 SLT (News) 87. 